\begin{tabular}{|c|c|}
\hline PORT SAID ENGINEERING RESEARCH JOURNAL \\
Faculty of Engineering - Port Said University \\
Volume (21) No. (2) September 2017 pp. $28: 36$
\end{tabular}

\title{
High-Performance Façade: Design Methods and Technologies
}

\author{
Osama M. Abo Eleinen ${ }^{\text {, Naglaa A. Megahed }}{ }^{2}$, and Rana M. El-Reialy ${ }^{3}$
}

\begin{abstract}
High-performance façade technologies are increasingly developed to provide architects and engineers with more effective solutions to improve our indoor and built environment. In this context, the highperformance facade can play a significant role in building energy performance and providing internal spaces with better thermal, visual and acoustic comfort. The objective of this paper is to present and analyze international case studies, which have utilized high-performance façade based on smart or/and nanotechnologies. In addition, the case studies buildings have been compared for their energy performance based in their passive design methods, strategies and recent technologies which have been used in each building façade to achieve a significant decrease in energy consumption and enhance a better environmental quality.
\end{abstract}

Keywords: Design methods- Energy consumption- High-performance façade- Nanotechnology Smart technology- Thermal comfort.

\section{INTRODUCTION}

Recently, the world's attention has been focused on saving energy, stopping the depletion of nonrenewable resources, and avoiding the negative effects of energy consumption on the environment. Most researchers confirm that the construction sector is responsible for the largest share of energy consumption [1]. This situation means that utilizing energy-efficient technologies in construction sector is considered one of the best approaches to save energy and protect our environment.

Particularly, building façade is considered one of the most essential elements responsible for the energy budget of a building and the provision of users' comfort [2]. In addition to being the separator between the interior and the exterior environment, the building façade should fulfill many other functions related to noise, rainwater, wind loads, cooling, shading and lighting strategies. Therefore, there is a growing awareness of the urgent need to overcome saving energy challenge through developing building facades, by integrating the most energy-efficient technologies into building facades to make the building more sustainable and energy self-sufficient [3]. This research explores two approaches based on these technologies - smart and nanotechnology.

${ }^{I}$ Assoc. Professor at Department of Architectural Engineering and Urban Planning, Faculty of Engineering, Port Said University.

${ }^{2}$ Assoc. Professor at Department of Architectural Engineering and Urban Planning, Faculty of Engineering, Port Said University.

${ }^{3}$ Architect at General Authority for Educational Buildings, Damietta Governorate, Egypt

\section{HIGH-PERFORMANCE FAÇADE}

It is an outer enclosure that uses the least possible amount of energy to maintain a better indoor environment, which promotes the health and productivity of the building's occupants [4]. This means that highperformance facades are not simply barriers between interior and exterior; they are building systems with creative design methods that create comfortable spaces by: a) developing building geometry to respond to solar position; b) allowing shading strategies; c) enhancing natural ventilation; and d) maximizing natural lighting and minimizing energy used for artificial lighting [2]. Therefore, it is necessary for the architect to study these design methods and factors influencing the performance of building façade, and be familiar with the most advanced technological means used to improve the façade performance and overcome the problems facing it.

\section{ANALYSIS EXAMPLES OF HIGH- PERFORMANCE FAÇADES:}

The following section will present an analysis of the building facade technologies to reduce energy consumption, eliminate greenhouse gasses, and improve indoor quality. This analysis will be based on the investigation of five international sustainable buildings, as a case study, with taking into consideration the smart and nanotechnologies used to enhance three main strategies; ventilation, daylighting and shading, and energy efficiency. Moreover, it will identify the most important technological means used to achieve the highest performance in every strategy associated with design 
methods, where, this research classified the technologies used in case study buildings into two types: smart and nanotechnology. So, the case study buildings have been selected based on the following criteria:

- These buildings won international awards for achieving the principles of green architecture and being environmentally friendly.

- These buildings achieved sustainability through adopting high-performance facades.

- These buildings are in changing climate zones, which requires facades utilizing advanced technology to overcome unstable climatic conditions, such as extreme heat, cold, wind, and humidity.

- Their facades have depended on the integration of smart and nanotechnologies to enhance their efficiency and performance.

\section{Based on these criteria, the selected case study buildings are:}

- EX1: Council House 2 (CH2), Melbourne, Australia.

- EX2: Jacobs Institute for Design Innovation, California, USA.

- EX 3: Masdar Headquarters, Abu Dhabi, UAE.

- EX4: Yale University Sculpture Building, New Haven, Connecticut, USA.

- EX5: Pearl River Tower, Guangzhou, China.

\subsection{Ex1: Council House 2 (CH2), Melbourne, Australia}

$\mathrm{CH} 2$ is an administrative building located the center of Melbourne [5], which have a highly inconsistent climate, where the weather sometimes is described as "four seasons in one day". In addition, the temperature in summers with warm to hot. Therefore, the variability in weather and environmental conditions had been taken into consideration before designing the building $[5,6]$. Based on its high-performance façade, the building has received many awards in the field of environmental planning and sustainable design [7].

Table 1: Ex1 description [6].

\begin{tabular}{c|l}
\multicolumn{2}{c}{ Council House 2 $(\mathrm{CH} 2)$} \\
\hline Architects & Design Inc Melbourne \\
\hline Location & Melbourne, Australia \\
Date & 2006 \\
& - Double glazing \\
Smart and & - Dynamic shutters made of \\
recycled timber \\
$\begin{array}{c}\text { nanotechnologies } \\
\text { integrated with }\end{array}$ & - Light shelves \\
efficient energy & - Daylighting sensors \\
strategies & - Wind turbine \\
& - PV cells \\
\hline
\end{tabular}

The building façades maximize energy efficiency and enhance user comfort, through three main strategies:

\section{A. Ventilation strategy:}

Building facades design tried to maximize the use of natural ventilation, where windows in north and south facades are directed to allow natural ventilation [6,7]. Also, covering the whole surface area of the north facade with vertical planting provides internal spaces with more fresh air [7].

In addition, building facades design reduced cooling loads through using double glazing in south façade, it acted as barriers to the internal heat gain into the building in summer, while preventing heat loss from the interior in winter [5].

\section{B. Daylighting and shading strategy:}

The building aims to maximize natural daylight penetration to the interior spaces with controlling in the glare, and reducing artificial lighting. In this context, efficient natural lighting is achieved through the following factors;

- The windows located to take maximum advantage of natural daylight. Moreover, windows on the north and south facades are larger on the lower floors than the upper ones, as lower floors receive less daylight [5].

- The glazing is specified to have a visible light transmittance above $50 \%$, with a solar transmittance below $35 \%$ [6].

- Using daylighting sensors in north and south facades to monitor the amount of daylight, and adjust the artificial light when required [7].

- The western façade is shaded by shutters made of recycled timbers, it protects the offices from the afternoon sun while enabling views for the users and permits natural light to enter the building. The shutters are opened and closed according to the sun path to enhance thermal comfort [6-7].

- Using blinds in the upper and lower parts of the windows to help in protecting from the direct sunlight without reducing the amount of daylighting [5].

- Vertical planting on north facades protect the office spaces from direct sunlight and help in controlling the glare [7], as shown in Figure 1.

\section{Energy efficiency strategy:}

In general, besides previous passive design methods, the building depends also in active methods to generate electricity. In this context, $\mathrm{CH} 2$ generates its own energy by using wind turbines and PV cells, this generated energy provides the building with electricity, hot water and reduces the cooling loads [8]. In addition, to reduce lighting and cooling loads, the building depended on:

- Using transparent highly insulated double glazing with timber window frames, which have low heat conductivity help in protection from heat gain and use daylighting $[5,6]$. 
- Using shutters made of recycled timbers on western façade protects the internal spaces from the undesired sunlight [7].

Based on these strategies, a major contribution is a reduction in energy consumption by $50 \%$. Where the high-performance façades of $\mathrm{CH} 2$ building achieve the following benefits $[4,8]$;

- Reduction of electricity consumption by $85 \%$.

- Reduction of the building emissions by $64 \%$ lower.

- Reduction of the interior temperature between 4 and $13 \mathrm{C}$.

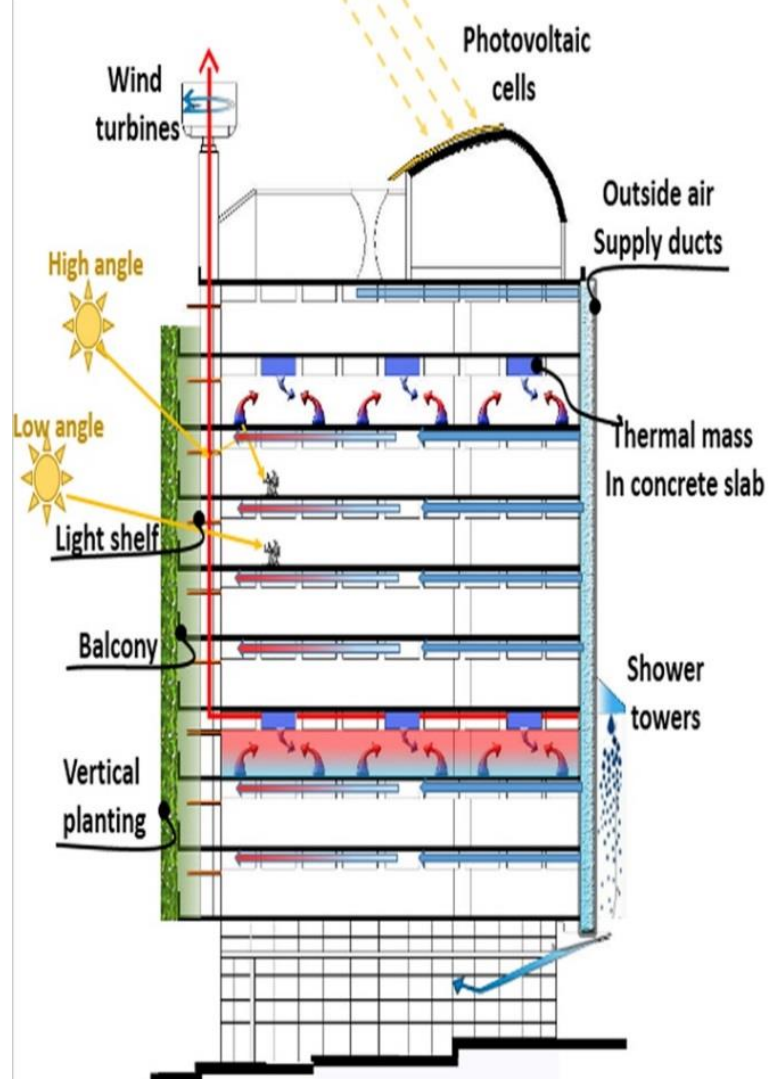

Figure 1: A schematic section for the energy efficient and sustainable features in $\mathbf{C H} 2$ building façade. Redrawn after [5-7]

3.2. EX2: Jacobs Institute for Design Innovation, California, USA

The Jacobs Institute was considered as an interdisciplinary center for students and teachers who work in design and technology fields. Where its architecture design reveals sustainable design innovation. The building received the highest sustainability award available in the United States, LEED Platinum Certification [9].

In addition, the project wined the AIA Committee on the Environment (COTE) award in 2016 [10].
Table 2: Ex2 description [10,11].

Jacobs Institute for Design Innovation

\begin{tabular}{c|l}
\hline Architects & Leddy Maytum Stacy Architects \\
Location & California, USA \\
Date & 2015 \\
$\begin{array}{c}\text { Smart and } \\
\text { nanotechnologies } \\
\text { integrated with } \\
\text { efficient energy } \\
\text { strategies }\end{array}$ & $\begin{array}{l}\text { - High thermal insulated glass } \\
\text { array }\end{array}$ \\
\hline
\end{tabular}

The building located in a warm climate; it is oriented on an east-west axis for the optimal solar benefit. This creates a wind protected, sunny courtyard to the south while enhancing building access to passive solar heating, daylighting, and natural ventilation [10].

The design of the building façades maximizes energy efficiency and user comfort while reducing first cost and long-term maintenance through three main strategies:

A. Ventilation strategy:

Building facades orientation allowed $100 \%$ of instructional spaces above the basement level to be naturally ventilated $[9,10]$.

- The building depends on mixed mode ventilation, where it uses openable windows and ceiling fans for natural ventilation, as shown in Figure 2. In addition to, the mechanical ventilation which provides fresh air when windows are closed, this ventilation mode providing $30 \%$ additional outside air above the code requirements [10].

- Internal spaces are heated by hydronic radiators, augmented by tempered mechanical ventilation air.

- The roof of the existing basement is reused as a southfacing courtyard enhances solar and natural ventilation access as well as creates a sunny outdoor space in warm conditions $[10,11]$.

B. Daylighting and shading strategy:

Although the university spaces require higher light levels than other spaces, total lighting loads were managed with efficient lighting and shading strategy; where $100 \%$ of instructional spaces above the basement, and $85 \%$ of all regularly occupied spaces depended on daylights [11]. This efficient strategy based on:

- The large north facing windows and interior glazing help to reduce internal glare [10]

- The PV array which extended on building roof works as sun shading for the building [9].

- The narrow building floor plate presents a shaded façade to the south for optimum daylight harvesting [10]. 


\section{Energy efficiency strategy:}

The project is designed to exceed the AIA 2030 commitment target, using $90 \%$ less energy than other university buildings. Integrated energy performance strategies and design methods through the building form, appearance and geometry, including simplified massing, high-performance facades and the cantilevered PV system, which provides $58 \%$ of the building's energy requirement $[9,10]$.

In addition, using a highly insulated glazing facade, rain screen cladding, sun shading and cool roof help in reducing heating, cooling, and lighting loads for the building [11].

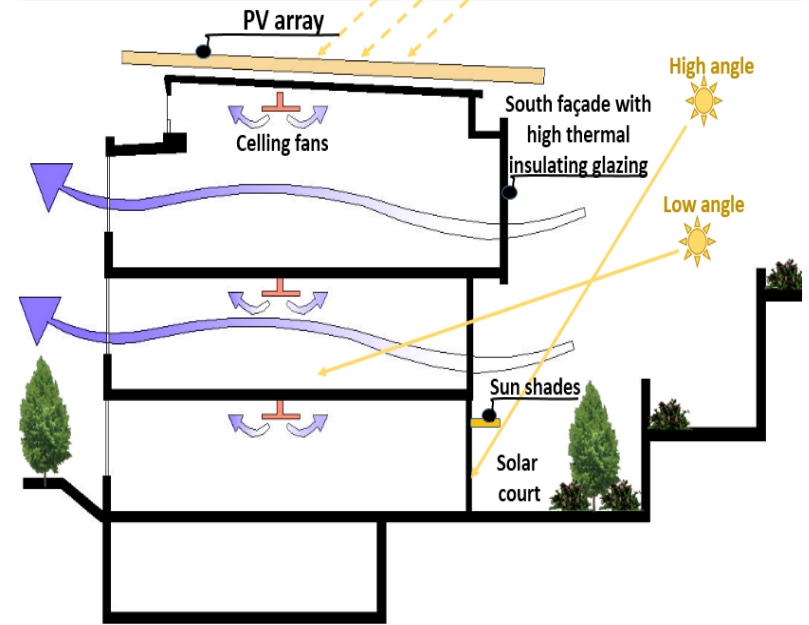

Figure 2: $100 \%$ of instructional spaces above the basement level enjoy abundant daylight and natural ventilation. Redrawn after [9-11]

\subsection{EX3: Masdar Headquarters, Abu Dhabi, UAE}

This project aims to, a zero-waste, zero-carbon emission development outside Abu Dhabi [12, 13]. It is the winner in 2008 with Cityscape Architectural Awards, Environmental Award and, Sustainable Design Award. In addition, it is the winner in 2010 with International Property Awards [15].

Table 3: Ex3 description [6, 16].

Masdar Headquarters

\begin{tabular}{c|l}
\hline $\begin{array}{c}\text { Architects } \\
\text { Location }\end{array}$ & $\begin{array}{l}\text { Adrian Smith and Gordon Gill } \\
\text { Abu Dhabi, UAE }\end{array}$ \\
$\begin{array}{c}\text { Smart and } \\
\text { nanotechnologies } \\
\text { integrated with } \\
\text { efficient energy } \\
\text { strategies }\end{array}$ & $\begin{array}{l}\text { High thermal- mass exterior glass } \\
\text { cladding }\end{array}$ \\
\hline
\end{tabular}

Masdar Headquarter located in a subtropical climate, with temperatures that vary from warm in winter months to hot in summer with sunny blue skies prevail throughout the year and rainfall is infrequent, which have effected on building architecture design to fulfill environmental and climatic requirements [6].
Building design overcomes the desert climate through depending on some sustainability approaches and design methods, which integrated within building facades to limit external heat gains and making use of natural cooling potentials, through three main strategies:

A. Ventilation strategy:

The building design includes ten wind cones, which considered as a signature architectural feature for the project. These cones provide the building with natural ventilation, cooling, and form the interior courtyards [6,12], as shown in Figure 3.

B. Daylighting and shading strategy:

The building facades depended on high thermal exterior glass cladding, which remains transparent to allow natural light into the building and blocks direct solar radiations $[6,13]$. Also, the wind cones provide the building's interiors with soft daylighting [6]. In addition to the lightweight PV cells which protect from the direct sun radiation [12].

\section{Energy efficiency strategy:}

Masdar Headquarter project targets to be the world's first zero-carbon headquarter, where the energy needed for cooling and lighting will be reduced by controlling the building orientation, its design, and presence of green spaces to find a balance between shade and sun, in addition, to promote natural-air circulation $[13,16]$.

Based on active methods, the project will feature the largest photovoltaic power generation system, which will produce more power than its needs by using renewable sources of energy generation (solar and wind energy) $[12,13]$. In addition to reducing solar gain and creating a cool internal environment, which reduces the need for air conditioning [6].

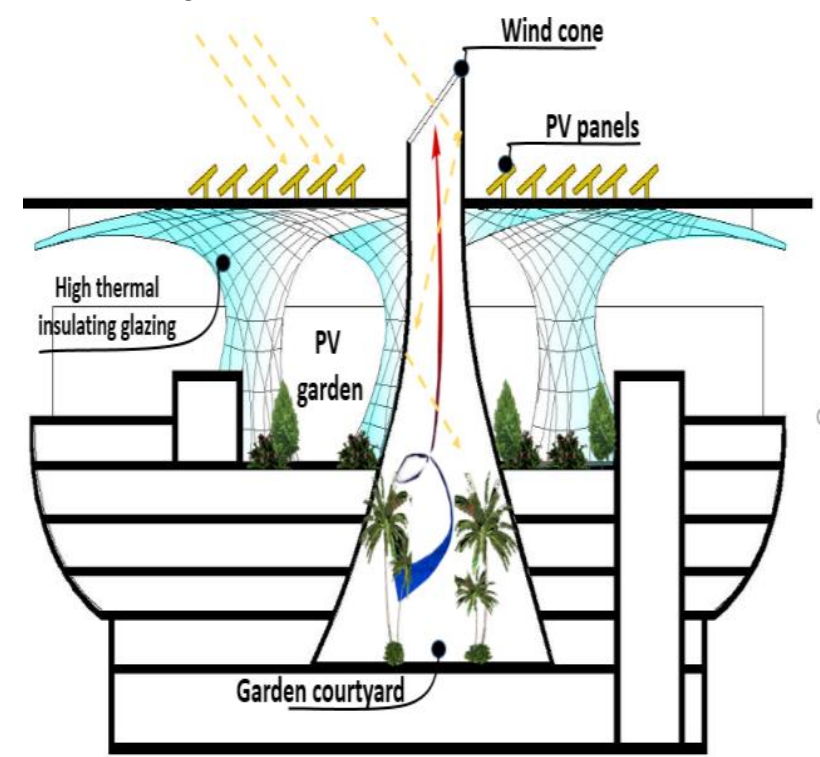

Figure3: Power generation from PV panels and shading techniques integrated in Masdar Headquarter Redrawn after $[6,12,13]$ 


\subsection{EX4: Yale University Sculpture Building, New Haven, Connecticut, USA:}

In the mid-1990s, Yale University undertook a tenyear plan for the enhancement of buildings associated with its highly-regarded programs in the arts [19]. The project wins the AIA Committee on the Environment (COTE) award in 2010, it also ultimately achieved a LEED silver rating, because of its structure's exceptional environmental performance resulted from the fully integrated design methods $[18,19]$.

Table 4: Ex4 description. [17, 19].

Yale University Sculpture Building

\begin{tabular}{|c|c|}
\hline Architects & $\begin{array}{l}\text { Kieran Timberlake Associates } \\
\text { LLP, Philadelphia }\end{array}$ \\
\hline Location & New Haven, Connecticut, USA \\
\hline Date & 2007 \\
\hline $\begin{array}{c}\text { Smart and } \\
\text { nanotechnologies } \\
\text { integrated with } \\
\text { efficient energy } \\
\text { strategies }\end{array}$ & $\begin{array}{l}\text { - Nanogel insulation material } \\
\text { - Triple-glazed with a low- } \\
\text { emittance } \\
\text { - Mixed mode ventilation system } \\
\text { - Operable windows and lighting } \\
\text { sensors }\end{array}$ \\
\hline
\end{tabular}

The most important targets that the project sought to achieve in its facades were to provide good insulation depend on natural lighting inside spaces at the same time and enjoy the picturesque view of the project site, through three main strategies:

\section{A. Ventilation strategy:}

The building depends on mixed-mode ventilation. While it includes operable windows, which allow the building to be naturally ventilated in spring and fall, it uses a displacement ventilation system, which supplies fresh air at low velocities and higher than usual temperatures, in addition, to protecting indoor air quality $[18,19]$.

\section{B. Daylighting and shading strategy:}

Building facades depends on transparent triple-glazed with nanogel material in its cavity (See Figure 4), which provides $2 \%$ daylight factor levels, as well as access to views of the surrounding environment. In addition, the south-facing windows were designed to provide daylighting without glare in the summer [17, 19]. Besides the gallery facade uses sunscreens made of reclaimed cedar to protect from direct sun radiations [18].

\section{Energy efficiency strategy:}

Using triple-glazed with nanogel in its double-cavity in building facades provide significant reductions in both heat gain and loss all year round. The warm air trapped in the curtain wall cavity is retained by the nanogel insulation and is either used internally in the winter months or vented to the exterior during the warm months. This creates an effective thermal management barrier, that increases energy performance [17].

In addition, concrete slabs in the building have been left exposed internally to reduce the demand for heating and cooling systems and to aid in the storage of recovered heat in winter $[18,19]$.

Based on smart technologies, the building facades design make the daylighting in the building at levels that allow lights to be off during daylight hours: $88 \%$, that's led to reducing the building lighting loads [18]. In addition to using high-efficiency lighting rely on occupancy sensors at 30-foot candles in all undergraduate classrooms, studios, graduate studios and fourth-floor lobby [19].

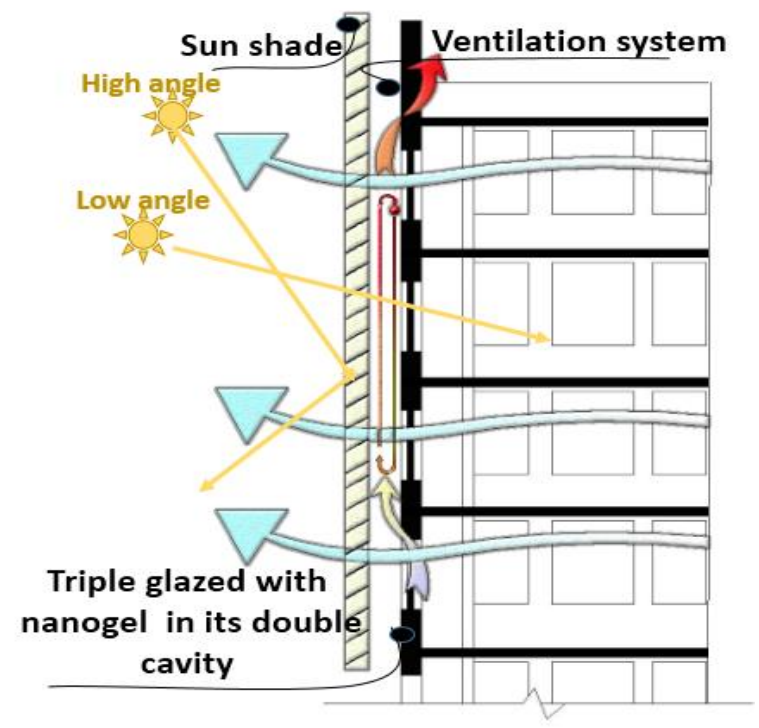

\section{Figure4: Shading and ventilation strategies in building south façade. Redrawn after [19]}

\subsection{EX5: Pearl River tower, Guangzhou, China}

It was awarded for green, carbon-lowering \& environmental category: Gold Award in 2008 [20].

Pearl River tower located in a hot and humid climate, where the heavy rain with predictable prevailing north, south and southwest winds. Summer season is long, wet, hot and humid; while winter is mild, dry, and free of snow with average mean temperature [6].

Table 5: Ex5 description. [6, 20].

Pearl River tower

Skidmore,Owings \& Merrill with

\begin{tabular}{c|l}
\hline Architects & $\begin{array}{l}\text { Skidmore,Owings \& Merrill with } \\
\text { partner Adrian Smith and Gordon } \\
\text { Gill }\end{array}$ \\
\hline $\begin{array}{c}\text { Location } \\
\text { Date }\end{array}$ & $\begin{array}{l}\text { Guangzhou, China } \\
\text { - Double and triple glazed with a } \\
\text { low-emittance }\end{array}$ \\
$\begin{array}{c}\text { Smart and } \\
\text { nanotechnologies } \\
\text { integrated with } \\
\text { efficient energy } \\
\text { strategies }\end{array}$ & $\begin{array}{l}\text { position control in façade blinds } \\
\text { - Wind turbines }\end{array}$ \\
& $\begin{array}{l}\text { Photovoltaic panels } \\
\text { - Hydrogen fuel cells } \\
\text { - Thin film coating }\end{array}$ \\
\hline
\end{tabular}


Pearl River tower's facades integrate various strategies as follows:

\section{A. Ventilation strategy:}

The dynamical structure of the tower and its orientation provides natural ventilation to its internal spaces, in addition to using chilled radiant ceiling instead of air conditioning [20]. In addition, the building depends on displacement ventilation, which provides it with fresh air, this ventilation cooled by the chilled water system and delivered via a raised access floor [21].

\section{B. Daylighting and shading strategy:}

Building facades design aim to provide the building with the optimum daylighting, by using high-performance curtain walls. The double-glazed system used in north and south façades, while a triple-glazed system with automated blinds used in east and west facades. In addition, a photovoltaic system integrated into the building's external shading system and glass outer skin, where, the blinds position is determined by photocells that track the sun position, which activates the shading system connected to the building management system to ensure the building occupants' comfort from solar gain and glare [6, 20].

\section{Energy efficiency:}

The building aims to consume nearly $60 \%$ less energy than a traditional building [21]. Where its curtain walls use an insulated tempered glass with a low-emittance coating (thin film coating, virtually invisible, metal layer that reduces thermal conductivity) is used in the exterior glazing layer, while an operable transparent glass panel is used in the in the interior glazing layer, which helps in decreasing cooling and heating loads $[6,20]$.

Besides mentioned strategies, the building also generates its required energy depending on renewable energy by using other technologies:

- Wind turbines, which used to catch prevailing wind from the south and the north. Therefore, the south façade design is curved to catch all prevailing wind to the mechanical floor [20, 21], as shown in Figure 5.

- Photovoltaic panels, which integrated into the south and the west facades [20, 21].

- Hydrogen fuel cells, which integrated into the building façades to store excess generated energy and convert gas to electricity with more than $\% 50$ energy efficiency, also it could be used for cooling and ventilation energy $[6,20]$.

All these active and passive methods and recent technologies work together to achieve zero energy building, ensure the highest level of human comfort and indoor air quality, and reduce energy.

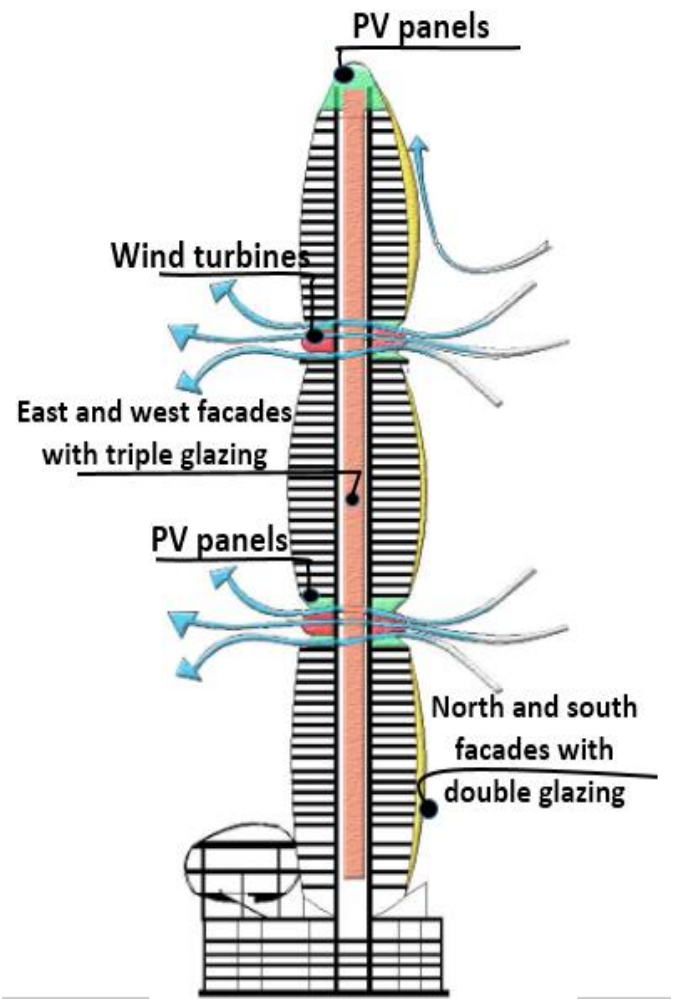

Figure 5: PV panels mounted to the exterior sunshades on the western façade. Redrawn after [6,20]

\section{DISCUSSION}

Based on the literature, the analyzed case study buildings have high-performance facades, which contributed in reducing building energy consumption, and achieved the principles of sustainability through depending on smart and nanotechnologies integrated with efficient energy strategies. This integration aims to:

- Provide internal spaces with the maximum amount of natural ventilation through best orientation and windows size. In addition to, using mixed mode ventilation in all previous case studies helping to achieve the optimum thermal performance with minimum cooling and heating loads.

- Provide the building with the optimum level of daylighting without glare to suit the activity in the building, where all the previous facades used transparent double or triple glazing systems, and some of them used daylighting devices and sensors. In addition to using high-performance shading systems to protect against unwanted sunlight, such as dynamic shutters and motorized blinds.

Table 6 compares between the five case studies which analyzed previously to clarify design methods, solar strategies and recent technologies which used in each building façade to achieve significantly decrease in energy consumption and better environmental quality. 
Table 6: Comparative analysis between the case study buildings: integrated design methods and technologies. Adapted from [ 5- 21]

\begin{tabular}{|c|c|c|c|c|}
\hline \multirow{2}{*}{ Examples } & \multirow{2}{*}{ Ventilation strategy } & \multicolumn{2}{|c|}{ Daylighting and shading strategy } & \multirow{2}{*}{ Energy Efficiency } \\
\hline & & Daylighting & Shading & \\
\hline $\begin{array}{l}\text { Council } \\
\text { House } 2 \\
\text { (CH2) } \\
\text { Melbourne, } \\
\text { Australia }\end{array}$ & $\begin{array}{l}\text { The windows are } \\
\text { located and oriented to } \\
\text { achieve the maximum } \\
\text { natural ventilation. } \\
\text { - North facade with } \\
\text { vertical planting } \\
\text { provides internal spaces } \\
\text { with more fresh air }\end{array}$ & $\begin{array}{l}\text { - Daylighting sensors in } \\
\text { north and south facades } \\
\text { - Double glazing in the } \\
\text { western façade. } \\
\text { - Low conductor timber } \\
\text { facades. } \\
\text { - Using lighting shelves. }\end{array}$ & $\begin{array}{l}\text { - Using shutters made of } \\
\text { recycled timber on } \\
\text { western façade } \\
\text { - Blinds in the upper and } \\
\text { lower part of the façade. } \\
\text { - Vertical planting on the } \\
\text { northern façade. }\end{array}$ & $\begin{array}{l}\text { - Lighting shelves. } \\
\text { - Visible light. } \\
\text { - Transmittance glazing. } \\
\text { - Glare control. } \\
\text { - Using wind turbines. } \\
\text { - PV cells }\end{array}$ \\
\hline $\begin{array}{c}\text { Jacobs } \\
\text { Institute for } \\
\text { Design } \\
\text { Innovation, } \\
\text { California, } \\
\text { USA }\end{array}$ & $\begin{array}{l}\text { - Operable windows } \\
\text { allow personal control } \\
\text { over ventilation. } \\
\text { - Mechanical ventilation } \\
\text { provides } 30 \% \text { fresh air } \\
\text { when windows are } \\
\text { closed. } \\
\text { - Cooling is provided by } \\
\text { natural and mechanical } \\
\text { ventilation system. }\end{array}$ & $\begin{array}{l}\text { - Large north facing } \\
\text { windows and interior } \\
\text { glazing help to reduce } \\
\text { internal glare. } \\
\text { - Using high thermal } \\
\text { insulated glass in } \\
\text { building facades }\end{array}$ & $\begin{array}{l}\text { - The extended PV array } \\
\text { on building roof works } \\
\text { as sun shading for the } \\
\text { building. } \\
\text { - The narrow building } \\
\text { floor plate presents a } \\
\text { shaded façade. }\end{array}$ & $\begin{array}{l}\text { - Integrated glass façade } \\
\text { to provide visual } \\
\text { transmissions, } \\
\text { enhancing daylight and } \\
\text { reduce artificial } \\
\text { lighting. } \\
\text { - PV cells. } \\
\text { - Mixed mode } \\
\text { ventilation. }\end{array}$ \\
\hline $\begin{array}{c}\text { Masdar } \\
\text { Headquarter, } \\
\text { Abu Dhabi, } \\
\text { UAE }\end{array}$ & $\begin{array}{l}\text { - Wind cons provide the } \\
\text { building with natural } \\
\text { ventilation. } \\
\text { - Interior garden } \\
\text { courtyards to enhance } \\
\text { better cooling. }\end{array}$ & $\begin{array}{l}\text { - High-thermal mass } \\
\text { exterior glass cladding } \\
\text { blocks direct solar } \\
\text { radiations. } \\
\text { - Wind cones. }\end{array}$ & $\begin{array}{l}\text { - Shaded roof garden. } \\
\text { - Roof and façade with } \\
\text { PV cells to reduce the } \\
\text { solar gain. }\end{array}$ & $\begin{array}{l}\text { - Using wind cones } \\
\text { reduce cooling and } \\
\text { lighting loads. } \\
\text { - Depending on PV } \\
\text { panels in generating } \\
\text { energy. }\end{array}$ \\
\hline $\begin{array}{c}\text { Yale } \\
\text { University } \\
\text { Sculpture } \\
\text { Building, } \\
\text { New Haven, } \\
\text { Connecticut, } \\
\text { USA }\end{array}$ & $\begin{array}{l}\text { - Large windows are } \\
\text { featured throughout the } \\
\text { studio spaces } \\
\text { - Displacement and } \\
\text { mixed mode ventilation } \\
\text { system. } \\
\text { - Operable windows } \\
\text { allow personal control } \\
\text { over ventilation. } \\
\text { - Air monitoring system. }\end{array}$ & $\begin{array}{l}\text { - Geometry and glazing } \\
\text { configurations affect } \\
\text { daylight levels and } \\
\text { distribution. } \\
\text { - Triple-glazed with } \\
\text { nanogel allows the } \\
\text { entire façade to admit } \\
\text { natural light into the } \\
\text { interior and reduces the } \\
\text { artificial lighting costs. }\end{array}$ & $\begin{array}{l}\text { - The sunscreens on the } \\
\text { gallery facades are } \\
\text { made of reclaimed } \\
\text { cedar. } \\
\text { - Curtainwall of triple } \\
\text { glazing and nanogel } \\
\text { translucent panels } \\
\text { blended with windows } \\
\text { and sunshades to create } \\
\text { active curtainwall } \\
\text { system. }\end{array}$ & $\begin{array}{l}\text { - High-performance } \\
\text { curtainwall with } \\
\text { nanogel reduces cooling } \\
\text { and lighting loads. } \\
\text { - Using internal lighting } \\
\text { sensors reduce lighting } \\
\text { loads used in artificial } \\
\text { lighting. }\end{array}$ \\
\hline $\begin{array}{l}\text { Pearl River } \\
\text { Tower } \\
\text { Guangzhou, } \\
\text { China }\end{array}$ & $\begin{array}{l}\text { - Dynamical structure and } \\
\text { orientation maximize } \\
\text { natural ventilation to its } \\
\text { internal spaces. } \\
\text { - Displacement } \\
\text { ventilation system. }\end{array}$ & $\begin{array}{l}\text { - Building facades design } \\
\text { and form aim to provide } \\
\text { the building with the } \\
\text { optimum daylighting }\end{array}$ & $\begin{array}{l}\text { Double glazed system } \\
\text { used on north and south } \\
\text { façades, while a triple } \\
\text { glazed system with } \\
\text { automated blinds used } \\
\text { on east and west } \\
\text { facades. }\end{array}$ & $\begin{array}{l}\text { - Insulated tempered } \\
\text { glass with a low- } \\
\text { emittance in facades } \\
\text { curtain walls allow } \\
\text { daylight to enter inside } \\
\text { the building. } \\
\text { - PV integrated into } \\
\text { shading system. } \\
\text { - Hydrogen fuel cells } \\
\text { - Wind turbines. }\end{array}$ \\
\hline
\end{tabular}


Based on this comparative analysis, the study found that designing a high-performance facade required studies related to the factors influencing the façade energy performance as well as using the appropriate materials, methods and technologies to overcome the obstacles that challenge designing façades, especially in hot climates. The most important targets the case studies sought to achieve in its facades were providing good insulation along with providing natural ventilation and daylighting as well as having picturesque view of the project site There is also another important aspect to reduce heating, cooling, and lighting loads by depending on mixed-mode ventilation besides using high thermal insulating materials. For example, Yale University facades used nanogel as an insulating material between glass layers, and Pearl River tower's facades which used thin film coating as an external insulating layer.

In addition, the integration of advanced technologies into building envelopes will provide environmentally interactive envelopes that can manage energy consumption associated with using efficient energy performance strategies.

Finally, to maximize the façade energy performance, most case study building seeks to generate electricity depending on renewable sources, such as using photovoltaics arrays and wind turbines.

\section{CONCLUSION}

This paper has presented the role of high-performance facades in energy conservation and enhancing the internal environment. This presentation based on the analysis of the case study buildings which have utilized different approaches with high-performance facades. The analysis illustrates the importance of taking account of passive design methods through natural ventilation, shading and lighting strategies along with the integration of smart devices and nanomaterials to achieve sustainable facades. Based on these passive design methods and integrating energy-efficient technologies with smart and nanotechnologies, the analyzed high-performance facades were successful in minimizing energy consumption and providing thermally and visually comfortable spaces for their occupants in different climates. With their low annual energy consumption, some buildings exceeded the energy standard requirements and won many international and prestigious awards. However, although these highperformance facades based on careful planning, design, and construction, they also require a careful operation, management, and continuous maintenance strategies to sustain their indoor and built environment.

\section{REFERENCES}

[1] NREA. (2010) "New and Renewable Energy Authority", Energy in Egypt annual report 2009/2010. Cairo: NREA; 411.

[2] Aksamija, A. (2013)"Sustainable Facades: Design Methods for High Performance Building Envelopes",
Published by John Wiley \& Sons, Inc. Hoboken, New Jersey, Canada.

[3] Linden, K. Boerstra, A. Raue, A and Kurvers, S. (2007)"Thermal Indoor Climate Building Performance Characterized by Human Comfort Response, Energy and Buildings".

[4] Gadelhak, M. (2013)"High Performance Facades: Designing Office Building Facades to Enhance Indoor Daylighting Performance", M.Sc. department of Architecture, faculty of Engineering, Ain University, Egypt.

[5] Webb, S. (2005)"The Integrated Design Process of $\mathrm{CH} 2$ ", Architecture press, Environment Design Guide.

[6] Dewidar, K. Mahmoud, A\& Magdy, N. (2014)"The Role of Intelligent Façades in Energy Conservation", an Imprint Thesis, department of architecture, faculty of engineering, The British University, Egypt.

[7] Jones, W. (2008)"Council House 2, Melbourne: Australia's greenest office building", http://www.building.co.uk/story.asp?storycode $=310$ 4100 (accessed May 2017)

[8] City of Melbourne. (2017)"Conserving energy and water". http://www.melbourne.vic.gov.au/buildingand-development/sustainable-building/councilhouse-2/conserving-energy-water/pages/conservingenergy-water.aspx (accessed May 2017)

[9] ALUCCOBOND. (2017)"LEED Platinum University Innovation Hub Features Alucobond PLUS Exterior" https://www.alucobondusa.com/blog/leed-platinumuniversity-innovation-hub-features-alucobond-plusexterior/\#.WgM4VFuCzIV (accessed November 2017)

[10] AIA. (2017)"Jacobs Institute for Design Innovation" http://www.aiatopten.org/node/482 (accessed October 2017)

[11] ArchDaily. 2016 "Jacobs Institute for Design Innovation / LMS Architects" https://www.archdaily.com/795685/jacobs-institutefor-design-innovation-lms-architects/ (accessed October 2017)

[12]E-architect. (2008)" Masdar Headquarters, Abu Dhabi", https://www.earchitect.co.uk/dubai/masdarheadquarters-abu-dhabi (accessed March 2017).

[13] Adrian Smith+ Gordon Gill Architecture. (2010)" Masdar Headquarters Project" http://smithgill.com/news/autodesk_23_sep_10/ (accessed November 2017)

[14] Justin/MetaEfficient. (2009)"Masdar Headquarters (UAE)"

http://www.solaripedia.com/13/91/778/masdar_head quarters_overview_(asgg)_(uae).html (accessed November 2017)

[15] Adrian Smith+ Gordon Gill Architecture. (2010)"Masdar Headquarters" smithgill.com/work/masdar_headquarters/ (accessed November 2017)

[16] Architect. (2012)"Masdar Headquarters, Adrian Smith + GordonGill Architecture" 
http://www.architectmagazine.com/project-

gallery/masdar-headquarters (accessed June 2017)

[17]Fouad, F. (2012)"NanoArchitecture and Sustainability", MSc, department of Architecture, faculty of Engineering, Alexandria University, Egypt.

[18] KieranTimberlake. (2008)" Yale Sculpture Building and Gallery" http://onlinelibrary.wiley.com/doi/10.1002/ad.853/e pdf (accessed October 2017)

[19] AIA. (2017)" Yale Sculpture Building and Gallery" http://www.aiatopten.org/node/126 (accessed May 2017)

[20] Roger, E. (2008)"Towads Zero Energy: A Case Study of the Pearl River Tower Guangzhou, China", SOM, Chicago, USA.

[21] Kyra Epstein. (2008)"How Far Can You Go? case Study: Pearl River Tower" High Performing Buildings. 